\title{
Erratum to: prostate cancer arising in ectopic prostatic tissue within the left seminal vesicle: a rare case diagnosed with multi-parametric magnetic resonance imaging and magnetic resonance imaging- transrectal ultrasound fusion biopsy
}

Alexander S. Somwaru ${ }^{1 *}$, Deepu Alex ${ }^{2}$ and Atif Zaheer ${ }^{3}$

\section{Erratum}

Unfortunately, the original version of this article [1] contained an error. The spelling of the author "Atif Zaheer" was misspelt "Atif K. Zaheer". This has been corrected in the original article and can also be seen correctly in the author list above.

\section{Author details \\ 'Department of Radiology, CCC Building, MedStar Georgetown University Hospital, 3800 Reservoir Road, N.W., Washington, DC 20007, USA. \\ 2Department of Pathology and Laboratory Medicine, MedStar Georgetown University Hospital, Washington, DC, USA. ${ }^{3}$ Russell H. Morgan Department of Radiology and Radiological Science, Johns Hopkins Medical Institutions, Baltimore, MD, USA.}

Received: 4 April 2016 Accepted: 4 April 2016

Published online: 26 April 2016

\section{Reference}

1. Somwaru SA, Deepu A, Zaheer A. Prostate cancer arising in ectopic prostatic tissue within the left seminal vesicle: a rare case diagnosed with multi-parametric magnetic resonance imaging and magnetic resonance imaging-transrectal ultrasound fusion biopsy. BMC Med Imaging. 2016;16:16.

\footnotetext{
* Correspondence: alexander.s.somwaru@gunet.georgetown.edu 'Department of Radiology, CCC Building, MedStar Georgetown University Hospital, 3800 Reservoir Road, N.W., Washington, DC 20007, USA

Full list of author information is available at the end of the article
}

Submit your next manuscript to BioMed Central and we will help you at every step:

- We accept pre-submission inquiries

- Our selector tool helps you to find the most relevant journal

- We provide round the clock customer support

- Convenient online submission

- Thorough peer review

- Inclusion in PubMed and all major indexing services

- Maximum visibility for your research

Submit your manuscript at

www.biomedcentral.com/submit 